\title{
Drought and frost tolerance in rhododendron collection of the Mlyňany Arboretum (Slovakia): a screening for future climate
}

\author{
Peter Ferus*, Peter Hot'ka, Jana Konôpková \\ Mlyňany Arboretum, Institute of Forest Ecology of the Slovak Academy of Sciences, \\ Vieska nad Žitavou 178, SK-95152 Slepčany, Slovak Republic
}

\begin{abstract}
Ferus, P., HoŤKa, P., Konôpková, J., 2017. Drought and frost tolerance in rhododendron collection of the Mlyňany Arboretum (Slovakia): a screening for future climate. Folia Oecologica, 44: 87-95.

Rhododendrons are jewels of the Mlyňany Arboretum, Institute of Forest Ecology of the Slovak Academy of Sciences (IFE SAS). Blossoming in May, they attract thousands of visitors. But recently these woody plants have much suffered from climatic extremes such as summer droughts and winter frosts, associated with the advancing climate change. To assess the rhododendron collection's stability, its drought and frost injury level were tested in field, in summer 2015 and winter 2017, respectively. The tested parameters were: leaf wilting and electrolyte leakage combined with shrub leaf area, insolation level and overall health state. We found that the drought effect was strong or very strong in only ca. $30 \%$ rhododendron species and ca. $10 \%$ rhododendron cultivars, and that around $60 \%$ shrubs showed no or only moderate symptoms of water deficit. The drought injury level was only associated with the genotype. The most tolerant / sensitive genotypes, commonly occurring in the park, were: $R$. catawbiense, $R$. ponticum, $R$. smirnowii, cv. 'Boursault', cv. 'Cunningham's White' and cv. 'Purpureum Elegans' / R. fortunei and cv. 'Tamarindos'. On the other hand, the most frequent response to frost in the observed rhododendron genotypes was moderate injury (28 and $37 \%$ for species and cultivars, respectively), nevertheless more than $18 \%$ species and almost $6 \%$ cultivars exhibited strong frost damage. Despite absence of significant differences in the factor-response between the species, we may suggest this decreasing sequence of the genotypes ordered according to their frost resistance: genotypes: cv. 'Cunningham's White' $>R$. decorum $>R$. fortunei and cv. 'Duke of York' $>R$. smirnowii $>$ cvs. 'Purpureum Elegans' and 'Tamarindos' $>$ R. macrophyllum and cv. 'Nova Zembla' $>R$. catawbiense $>R$. ponticum. These results have been compared with similar works in rhododendron species/cultivars as well as suggested species drought/frost tolerance derived from climatic conditions in the area of their natural distribution.
\end{abstract}

\section{Keywords}

climate change, cultivars, drought and frost tolerance, North-American, Pontic and Chinese native species, rhododendron

\section{Introduction}

Rhododendrons (Rhododendron sp.) represent a group of delightful plants beautifying numerous gardens, parks and arboretums (REILEY, 2004). In the virtual arboretum of Hirsutum.info, there are listed 1,279 rhododendron species and almost 14,600 cultivars. Both species and cultivars have similar natural requirements: moisture-retentive soils, temperate climate with rain and mist during the growing season (Cox, 1985). Rhododendrons grow best in the shelter of a woodland setting- protecting them from sun's hottest rays, drought and severe cold (NELSON, 2000).

The fifth assessment report of the International Panel on Climate Change (PACHAURI and MeYer, 2015) states more precisely negative consequences of climate

*Corresponding author:

e-mail: peter.ferus@savba.sk

(C) 2017 Authors. This is an open access article under the CC BY-NC-ND license (http://creativecommons.org/licenses/by-nc-nd/3.0/) 
change on the global level, among them surface temperature growth, alternations in precipitation distribution and increasing frequency of extreme events occurrence. The application of the recent climate change models for Slovakia has revealed a dramatic increase in the average monthly air temperatures and - except of summer months - also precipitation sums extrapolated up to year 2075 (Melo, 2003). The environmental study on the climate change consequences in the Nitra region (ŠEmBERA et al., 2015) refers to droughts and floods as the most negative climate change impacts in the Požitavie-Širočina micro-region in which the Mlyňany Arboretum IFE SAS is situated. Despite the global warming, the frequency of low temperature extremes (below $-15^{\circ} \mathrm{C}$ ) in the course of last 35 years stayed on the 4-5 years period but the cold episodes moved from December-January to January-February. Moreover, there occur much more late (vegetation) frosts.

According to Kelly (1994), drought and cold winter represent the second and fifth top causes of rhododendron death. Prolonged drought markedly affects look of these shrubs by leaf wilting, colour defects and precocious fall-off, lower vegetative growth, phenological anomalies, and in extreme cases by branch/ plant die-back (CAMERon et al., 2008; Augé et al., 2003). However, in case of soil water deficit after inflorescence initiation, rhododendrons flower sooner with richer inflorescence (SHARP et al., 2009). Late frosts can impair flower development. When undeveloped, the flower buds turn brown and drop off (ANTONELLI et al., 2006). Winter frosts usually work through leaf desiccation and photo-oxidative damage (NEUNER et al., 1999), as well as through direct disintegration of cell membranes by ice-crystals, causing cell solute elution (LARCHER, 2003).
Just a few studies testing evergreen woody plants suitability for Middle-European climate have been conducted. Recently, a small survey on rhododendron growth and flowering parameters in frost- or droughtprone environment, giving an indirect view of their tolerance to these abiotic constraints, have been published (LUKÁČIK et al., 2011). Another work dealing with winter hardiness of Mediterranean ornamental woody plants comes from the last year (ALKURDI and SUPUKA, 2016).

Thus, because of the expected rise in frequency of the above-mentioned extreme events, based on screening of wilting and electrolyte leakage level, we studied drought and frost tolerance of the whole rhododendron collection in the Mlyňany Arboretum IFE SAS, which represent one of the top attractions for visitors in late spring. Based on the obtained results, we have proposed recommendations for our park management as well as for horticultural practice.

\section{Material and methods}

\section{Rhododendron test collection}

The rhododendron collection in the Mlyňany Arboretum IFE SAS, comprising 18 botanical species and 15 cultivars (Table 1), was subjected to analysis of summer-drought-driven injury just before the start of irrigation. Then three individuals of rhododendron species/ cultivars commonly growing in different locations/light conditions of the arboretum and one shrub from those less frequently (in one location) grown, were analyzed for winter frost tolerance. Health state of all screened shrubs was recorded, too.

Table 1. Rhododendron species and cultivars in the Mlyňany Arboretum IFE SAS analyzed for drought stress level

\begin{tabular}{|c|c|c|c|}
\hline Species & Number & Cultivar & Number \\
\hline R. augustinii & 2 & R. catawbiense 'Album' & 2 \\
\hline R. catawbiense & 4 & R. $\times$ 'Anushka' & 1 \\
\hline R. caucasicum & 1 & R. × 'Balalaica' & 2 \\
\hline R. dauricum & 3 & $R . \times$ 'Boursault' & 4 \\
\hline R. decorum & 8 & $R . \times$ 'Cunningham's White' & 19 \\
\hline R. fargesii & 2 & $R . \times$ 'Darius' & 1 \\
\hline R. fortunei & 16 & R. $\times$ 'Dreamland' & 2 \\
\hline R. keiskei & 2 & $R . \times$ 'Duke of York' & 4 \\
\hline R. macrophyllum & 7 & R. catawbiense 'Grandiflorum' & 1 \\
\hline R. makinoi & 1 & R. $\times$ 'Marlis' & 1 \\
\hline R. maximum & 2 & R. $\times$ 'Nova Zembla' & 4 \\
\hline R. micranthum & 1 & R. $\times$ 'Polaris' & 2 \\
\hline R. orbiculare & 1 & R. catawbiense 'Purpureum Elegans' & 11 \\
\hline$R$. oreodoxa & 2 & $R . \times{ }^{\prime S n e e z y '}$ & 1 \\
\hline R. palustre & 1 & R. $\times$ 'Tamarindos' & 5 \\
\hline R. ponticum & 6 & & \\
\hline R. smirnowii & 7 & & \\
\hline R. yunnanense & 1 & & \\
\hline Total & 67 & Total & 60 \\
\hline
\end{tabular}




\section{Drought damage}

Drought-impact was assessed on July 6, 2015, after 26 days without substantial precipitation (Fig. 1A), when visual effect of water shortage was apparent. The leaf wilting degree in the rhododendron individuals was expressed through the following scale: 0 - no wilting, 1 - moderate wilting, 2 - medium wilting, 3 - strong wilting, 4 - very strong wilting. Thereafter, shrub leaf area (SA) was estimated according to SPANN and HEEREMA (2010), using the formula:

$$
\mathrm{SA}=\mathrm{A} \times \mathrm{T} \times \mathrm{S}\left(\mathrm{m}^{2}\right)
$$

where $\mathrm{A}$ is the average individual leaf area calculated as an ideal ellipse $\left(\mathrm{m}^{2}\right)$, T is leaf number per a twig, and $\mathrm{S}$ is twig number per a shrub.
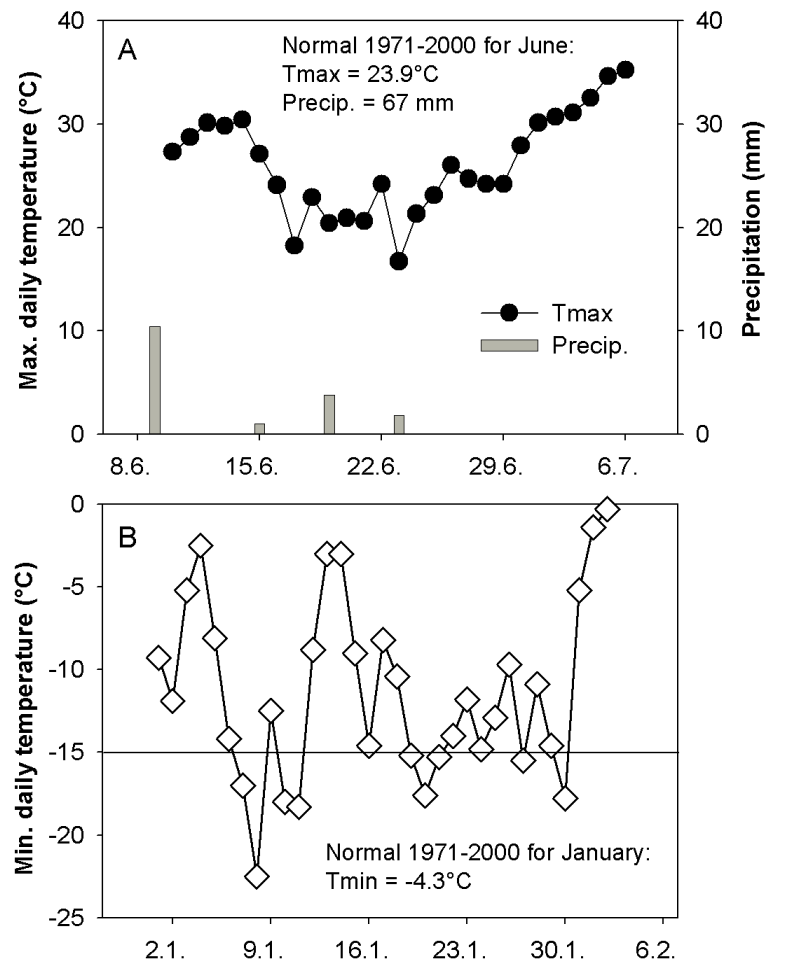

Fig. 1. Maximal daily temperature and precipitation in June 2015 (A) and daily temperature minimum in January 2017 (B) for the Mlyňany Arboretum IFE SAS, periods just before rhododendron drought and frost susceptibility testing, respectively.

Simultaneously, shrub exposition to sunlight, according to the daily course of light energy input, was defined:

$$
\operatorname{EXP}_{\mathrm{S}}=\operatorname{SUM}\left(\mathrm{E}_{\mathrm{n}} \times \mathrm{L}_{\mathrm{n}}\right) \text {, }
$$

where $\mathrm{EXP}_{\mathrm{S}}$ is total daily summer exposition, $\mathrm{E}$ is energy input coefficient for a compass point $n$, and $L$ is exposition level for a compass point $\mathrm{n}$ (full light -1 , shade - 0.2). Energy input coefficients for respective compass points are: East - 1, East-South-East - 1.75,
South-East - 2.45, South-South-East - 2.75, South 3 , South-South-West -2.75 , South-West -2.45 , WestSouth-West -1.75 , West -1 .

\section{Frost damage}

Rhododendron shrub injury caused by frost was investigated in winter 2016/17, just after 2 weeks lasting period of minimal air temperatures oscillating around -15 ${ }^{\circ} \mathrm{C}$ (Fig. 1B). In February 2017, on the first day with above-zero morning temperature, leaves from exposed parts of the shrubs were collected, dried on surface and submerged into $50 \mathrm{ml}$ distilled water and incubated for $24 \mathrm{~h}$ at the lab temperature. Then, the leaves were frozen in liquid nitrogen and placed into the same capped glass for a next $24 \mathrm{~h}$ incubation at the lab temperature. After both incubations, leaf leachate conductivity was measured using a portable $\mathrm{pH} /$ conductometer Jenway Enterprise 430 (Jenway, UK). The injury caused by frost (FI) was determined following this calculation proposed by Lim et al. (1998):

$$
\mathrm{FI}=\mathrm{C}_{\mathrm{F}} \times 100 / \mathrm{C}_{\mathrm{N}}(\%) \text {, }
$$

where $\mathrm{C}$ is leaf leachate conductivity $\left(\mu \mathrm{S} \mathrm{cm}^{-1}\right)$ of fresh leaves $\left(_{F}\right)$ and leaves frozen in liquid nitrogen $\left(_{N}\right)$.

Thereafter, all of the shrubs were ranked into following frost injury level categories: 1 - weak injury (FI $<10), 2$ - moderate $(10 \leq \mathrm{FI}<15), 3$ - medium $(15 \leq \mathrm{FI}$ $<20), 4-$ strong $(20 \leq \mathrm{FI}<25)$ and 5 - very strong $(\mathrm{FI} \geq$ $25)$. Data on frost injury were related to the leaf insolation level, which was approximated using the formula:

$$
\operatorname{EXP}_{\mathrm{W}}=\operatorname{SUM}\left(\mathrm{E}_{\mathrm{n}} \times \mathrm{L}_{\mathrm{n}}\right) \text {, }
$$

where $\mathrm{EXP}_{W}$ is the total daily winter exposition, $\mathrm{E}$ is energy input coefficient for the compass point $n, L$ is exposition level for the compass point $\mathrm{n}$ (full light -1 , shade -0.2 ). The energy input coefficients for respective compass points are: South-East -1 , South-SouthEast -2.15 , South -2.85 , South-South-West -2.15 , South-West -1 .

\section{Health state}

Parallel to the above described analyses, a screening of rhododendron health state using a description scale proposed by JuHÁsová and SERBINOvá (1997) was carried out. Four health state categories were distinguished in the rhododendron shrubs: 0 - shrubs are healthy, without any symptoms, 1 - damage sparsely occurring in shrubs (weak injury), 2 - presence of pathogens causing partial crown thinning and small cavitation without effect on shrub stability (moderate injury), 3 - one third of crown died, with major cavitation formed in the trunk, individual is suitable for further cultivation after treatment (medium injury). A detailed analysis of the health state of the Mlyňany Arboretum IFE SAS rhododendron collection has been published by FERUS et al. (2016). 


\section{Statistical analysis}

The drought and frost injury level data from the most frequently cultivated rhododendron species/cultivars in Mlyňany Arboretum IFE SAS were submitted to multivariate analysis of variance (shrub leaf area, insolation level, health state) for identification of the determining factors as well as drought and frost tolerance groups (R software v. 3.4.1). After analysis of data distribution (not normal - Poisson and Quasipoisson, respectively), wilting and frost injury level dependence on factors or their interactions were determined. Thereafter, principal factors defining plant responses to drought and frost were identified. Then clustering procedure revealed the optimal number of groups with species/cultivar distribution.

\section{Results}

\section{Drought damage}

Almost four weeks without substantial rainfall in the Mlyňany Arboretum IFE SAS affected almost 70\% rhododendron species and cultivars (Fig. 2A). More than $28 \%$ species showed moderate and almost $24 \%$ strong leaf wilting and around $15 \%$ shrubs exhibited medium and $3 \%$ very strong wilting. In cultivars, a decreasing trend in shrub number (from 35 to $0 \%$ ) with growing drought injury level was observed.

Analysis of most abundant rhododendron species (Fig. 2B) revealed moderate wilting in $R$. decorum and $R$. smirnowii, strong one in $R$. fortunei, and no wilting in $R$. ponticum as the most frequent responses. $R$. catawbiense showed a balanced number of shrubs in the first two categories (no wilting and moderate wilting) and $R$. macrophyllum from no to strong wilting.

On the other hand, leaves of cv. 'Cunningham's White' usually did not wilt (Fig. 2C), and in cv. 'Purpureum Elegans' the largest number of individuals shared the first two drought injury categories. Cultivar 'Duke of York' was dominated by moderate leaf wilting, 'Nova Zembla' by medium wilting, and in cvs. 'Boursault' and 'Tamarindos' we found only moderate and strong wilting, respectively.

From the rest of rhododendron genotypes in the Mlyňany Arboretum IFE SAS, the no wilting (category 0 ) was mainly observed in $R$. palustre, $R$. micranthum and cv. 'Marlis'; moderate wilting (category 1 ) in $R$. augustinii, $R$. caucasicum, $R$. oreodoxa, $R$. yunnanense, cv. 'Anushka', cv. 'Darius' and cv. 'Sneezy'; medium wilting (category 2) in R. fargesii, R. makinoi, R. maximum, cv. 'Album', cv. 'Balalaica', cv. 'Dreamland' and cv. 'Polaris'; and strong wilting (category 3 ) in $R$. dauricum, $R$. keiskei, $R$. orbiculare and cv. 'Grandiflorum'.

The statistical analysis revealed that the only factor responsible for the rhododendron response to drought was the genotype (Table 2, P-value 0.0043), which explained 54\% variability. Neither shrub leaf area, insolation level and health state, nor their interactions showed any effect on this response. Three groups of genotypes with different drought tolerance were distinguished (Fig. 3): 1. tolerant one comprising R. catawbiense, $R$. ponticum, $R$. smirnowii and cv. 'Boursault', 'Cunningham's White' and cv. 'Purpureum Elegans', 2 . intermediate one with $R$. decorum, $R$. macrophyllum, and cv. 'Duke of York' and cv. 'Nova Zembla', and 3. sensitive group where $R$. fortunei and cv. 'Tamarindos' belonged.
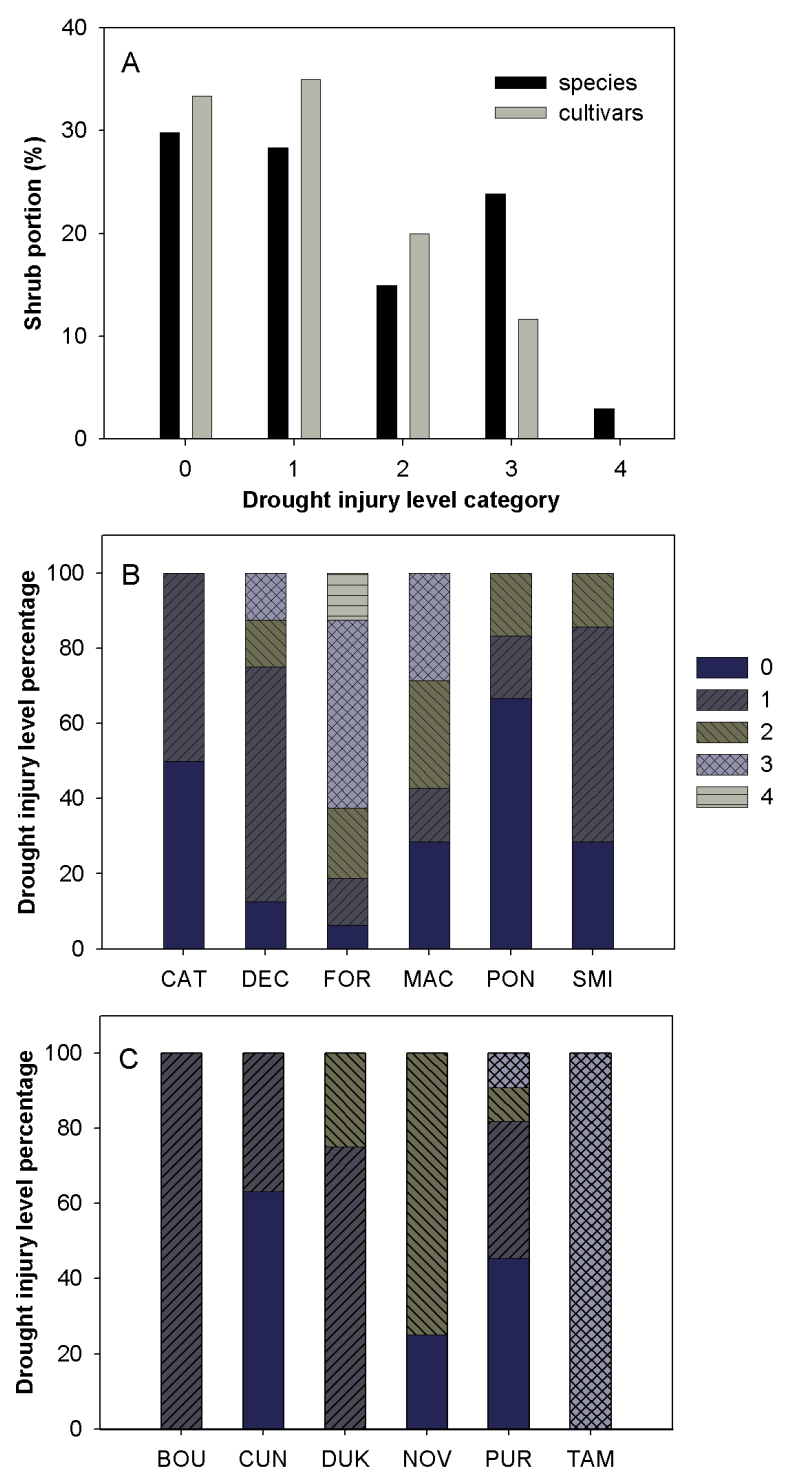

CAT, $R$. catawbiense; DEC, $R$. decorum. FOR, $R$. fortu$n e i$; MAC, $R$. macrophyllum; PON, $R$. ponticum; SMI, $R$. smirnowii; BOU, cv. 'Boursault'; CUN, cv. 'Cunningham's White'; DUK, cv. 'Duke of York'; NOV, cv. 'Nova Zembla'; PUR, cv. 'Purpureum Elegans'; TAM, cv. 'Tamarindos'.

Fig. 2. Drought injury levels in complete rhododendron species and cultivar collections of the Mlyňany Arboretum IFE SAS (A), and its detailed analysis in the most frequent species (B) and cultivars (C), respectively. 
Table 2. Statistical relevance of analysed factors in rhododendron drought and frost response

\begin{tabular}{cccccc}
\hline Factor & Df & Deviance resid. & Df & Resid. dev. & P-value \\
\hline Drought damage & & & & & \\
NULL & & & 94 & 54.832 & $0.0043^{* *}$ \\
Genotype & 11 & 27.1856 & 83 & 27.647 & 0.6505 \\
Shrub leaf area & 1 & 0.2053 & 82 & 27.441 & 0.1692 \\
Insolation level & 1 & 1.8900 & 81 & 25.551 & 0.9189 \\
Health state & 1 & 0.0104 & 80 & 25.541 & 0.1395 \\
Frost damage & & & & & 0.1901 \\
NULL & & & 45 & 102.775 & 0.7730 \\
Genotype & 14 & 39.731 & 31 & 63.044 & 59.583 \\
Insolation level & 1 & 3.461 & 30 & 59.416 & \\
Health state & 1 & 0.168 & 29 & & \\
\end{tabular}

**statistical significance.

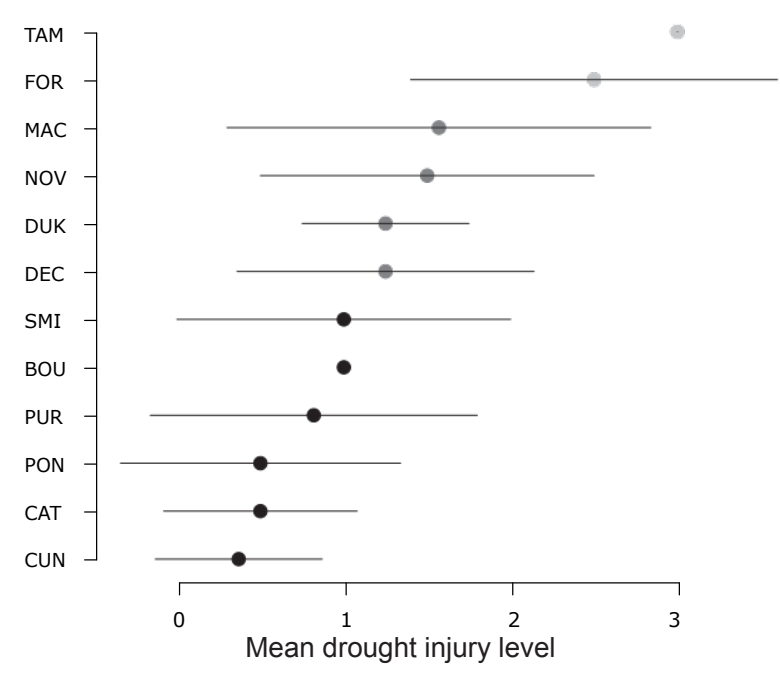

TAM, cv. 'Tamarindos'; FOR, R. fortunei; MAC, R. macrophyllum; NOV, cv. 'Nova Zembla'; DUK, cv. 'Duke of York', DEC, $R$. decorum; SMI, R. smirnowii; BOU, cv. 'Boursault'; PUR, cv. 'Purpureum Elegans', PON, R. ponticum; CAT, $R$. catawbiense; CUN, cv. 'Cunningham's White'.

Fig. 3. Drought tolerance-based clustering of rhododendron species/cultivars in the Mlynnany Arboretum IFE SAS. Points and lines represent mean wilting level category $\pm \mathrm{SD}$.

\section{Frost damage}

Evaluating the percentage of leachate released just after frost period termination (Fig. 4A), we found that most of rhododendron species and cultivars were moderately injured (28.1 and 37.1\%, respectively). Then, about $20 \%$ shrubs exhibited weak, medium and very strong frost injury among species. The strong one was identified only in $12.5 \%$ individuals. In the cultivars, the second largest portion of plants (31.4\%) showed medium frost injury, around $17 \%$ plants weak one and less than $10 \%$ strong and very strong frost damage.
As presented in Fig. 4B, $R$. decorum showed predominantly weak frost damage, $R$. macrophyllum medium one and $R$. ponticum very strong frost injury. The rest three rhododendron species exhibited larger response variability: in $R$. fortunei and $R$. smirnowii displayed around moderate and in $R$. catawbiense around medium frost injury.

The most frequently planted rhododendron cultivars in the Mlyňany Arboretum were generally less sensitive to the winter frost (Fig. 4C). The cv. 'Cunningham's White' showed only weak injury, cv. 'Purpureum Elegans' and cv. 'Tamarindos' mostly moderate eone, and cv. 'Nova Zembla' predominantly medium frost injury. The response of cv. 'Duke of York' varied around moderate damage.

From the other rhododendron genotypes present in the Mlyňany Arboretum IFE SAS, FI category 1 was most frequently found in $R$. augustinii, $R$. yunnanense, cv. 'Album' and cv. 'Darius'; category 2 in $R$. dauricum, $R$. makinoi, $R$. micranthum, $R$. orbiculrare and cv. 'Balalaica'; category 3 in $R$. caucasicum, R. oreodoxa, cv. 'Boursault', cv. 'Schneewolke' and cv. 'Sneezy'; category 4 in $R$. fargesii, $R$. keiskei, $R$. maximum, cv. 'Anushka', cv. 'Dreamland' and cv. 'Love Song'; and category 5 in $R$. palustre, cv. 'Marlis' and cv. 'Polaris'.

Despite the statistical analysis did not allow us either to identify any from considered factors as a decisive one for the rhododendron frost injury level (Table 2) or to specify response groups, suggestions about the rhododendron frost tolerance could be: cv. 'Cunningham's White' $>R$. decorum $>R$. fortunei and cv. 'Duke of York' $>$ R. smirnowii $>$ cvs. 'Purpureum Elegans' and 'Tamarindos' $>R$. macrophyllum and cv. 'Nova Zembla' $>R$. catawbiense $>R$. ponticum. 

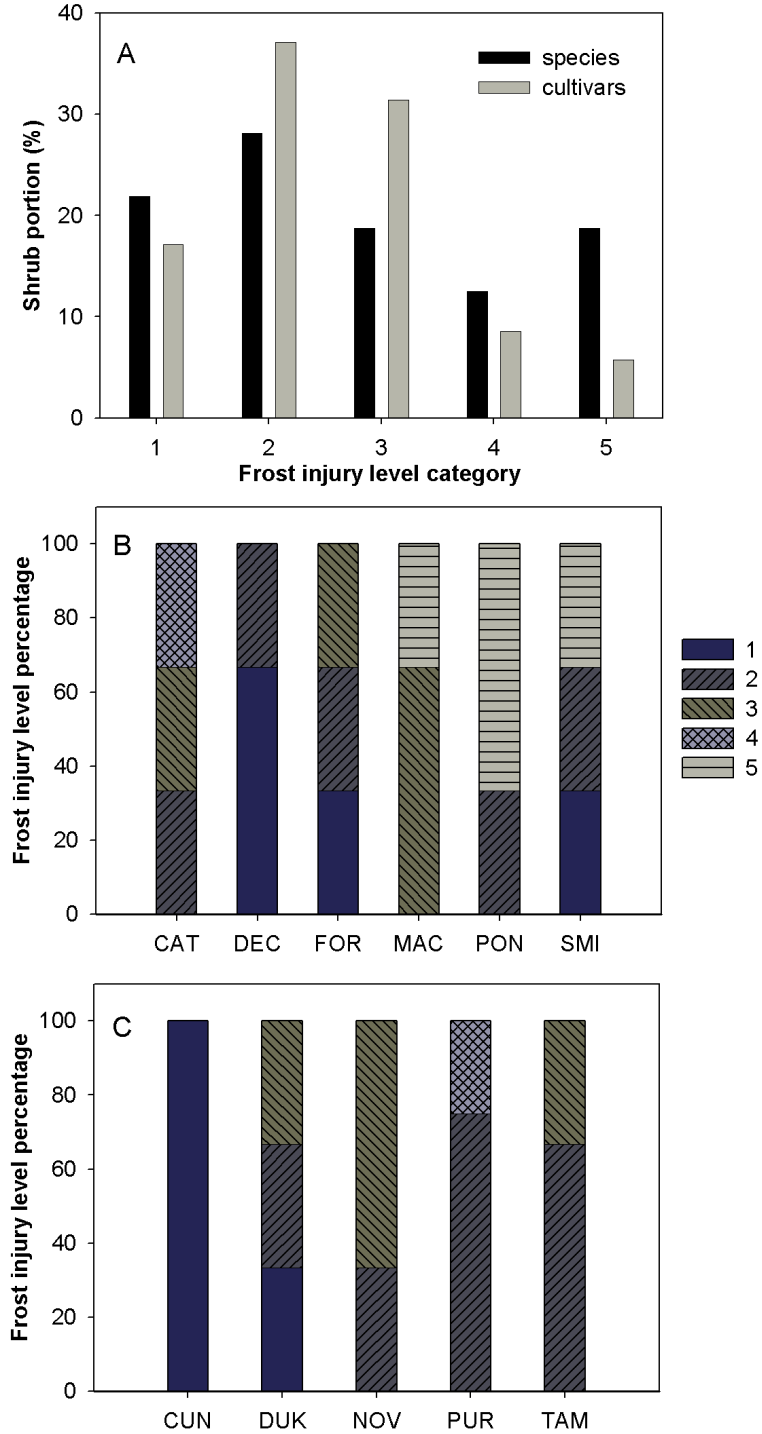

CAT, $R$. catawbiense; DEC, $R$. decorum; FOR, $R$. fortunei; MAC, $R$. macrophyllum; PON, $R$. ponticum; SMI, $R$. smirnowii; BOU, cv. 'Boursault'; CUN, cv. 'Cunningham's White'; DUK, cv. 'Duke of York'; NOV, cv. 'Nova Zembla'; PUR, cv. 'Purpureum Elegans'; TAM, cv. 'Tamarindos'.

Fig. 4. Frequency of respective frost injury levels in the Mlyňany Arboretum IFE SAS rhododendron species and cultivar (A) with focus on the mostly present species (B) and cultivars (C), respectively.

\section{Discussion}

Rhododendron species originating in different parts of the world and rhododendron cultivars with unknown genetic background cultivated in botanical gardens/arboretums can often suffer from local climatic extremes such as drought and/or frost, accelerated by continuing climate change. June 2015 and January 2017 in Mlyňany Arboretum IFE SAS - compared to the climatic normal 1971-2000 - can be ranked as very dry and extremely cold episodes, respectively (ŠIŠKA et al., 2005).
Our survey revealed a wide range of response to drought stress in the rhododendron collection in the Mlyn̆any Arboretum IFE SAS. Neither the total shrub leaf area nor insolation level as well as health state played a role in the final response of a rhododendron shrub. The only factor defining the response to severe drought was the genotype. The most tolerant species were $R$. catawbiense, $R$. ponticum, $R$. smirnowii, cv. 'Boursault', 'Cunningham's White' and 'Purpureum Elegans' (Fig. 5). As the least tolerant $R$. fortunei and cv. 'Tamarindos' were indicated.

A Chinese research on drought tolerance of 6 rhododendron species showed that $R$. fortunei can stand much larger soil water deficit than $R$. decorum (ZHANG et al., 2002). Thereafter, CoRdERo and NiLSEN (2002) observed a fifty percent loss of stem hydraulic conductivity in $R$. catawbiense, $R$. maximum and $R$. macrophyllum at leaf water potential $-1.75,-2.42$ and -2.96 $\mathrm{MPa}$, respectively. However, we found just an opposite order. Due to the high aesthetic value and probably also relatively high drought sensitivity, $R$. fortunei recently became a model plant species for physiological studies - water regime, photosynthesis and antioxidant system (e.g. KE, 2007; KE and YANG, 2007a; KE and YANG, 2007b).

Although we observed no statistical difference in the rhododendron frost tolerance as a result of genotype, insolation level and health state, susceptibility to low temperatures could be suggested. The lowest frost injury level was exhibited by leaves of cv. 'Cunningham's White' and the highest one by those of $R$. ponticum (Figure 4).

A study of CAPRAR et al. (2011) brought a comparison of frost tolerance in 27 Rhododendron species, based on a 10-point scale evaluation. From those species present in the Mlyňany Arboretum IFE SAS, as well, they recorded no damage in $R$. caucasicum, $R$. catawbiense and $R$. ponticum, only. In $R$. decorum partial frost-caused dieback of older branches, in $R$. oreodoxa above-ground part dieback, and in $R$. fortunei whole plant dieback, were observed. CzEKALSKI (1982), referring to negative consequences of extremely cold winter in 1978/1979 in Poland, observed the least damage in $R$. smirnowii and $R$. maximum, followed by $R$. catawbiense 'Hybridum' and cv. 'Cunningham's White'. Similar to our research, the last author found the most frost sensitive $R$. ponticum. According to CORDERO and NILSEN (2002), R. catawbiense had the highest percent loss of stem hydraulic conductivity and suffered from the highest embolism in response to the freezing treatment, compared to $R$. macrophyllum and $R$. maximum. This finding is in accordance with our survey on frost damage.

Behavioural questions in respect to freezing stress have been widely studied particularly in $R$. catawbiense. For instance, ANisko and Lindstrom (1996) followed the seasonal changes in this species cold resistance, as influenced by summer drought events, WEI et al. (2006) focussed on gene expression for lipid per- 
oxidation, membrane transport and lignin biosynthesis under cold acclimation process, and PENG et al. (2008) tested transgenic Arabidopsis plant overexpressing RcDhn5 gene for cold acclimation-responsive dehydrin from $R$. catawbiense.

Combining the data from our drought and frost damage surveys, more groups of mostly present rhododendron species/cultivars can be distinguished showing: 1. extraordinary drought and frost tolerance (cv. 'Cunningham's White'), 2. medium drought and frost tolerance (cv. 'Purpureum Elegans' and R. smirnowii), 3. lower drought and frost tolerance (cv. 'Nova Zembla' and $R$. macrophyllum), 4. high drought but low frost tolerance ( $R$. catawbiense and $R$. ponticum), 5. medium drought but high frost tolerance ( $R$. decorum and cv. 'Duke of York'), 6. low drought but high frost tolerance (R. fortunei) and 7. low drought and medium frost tolerance (cv. 'Tamarindos').

A long term study on recent rhododendron cultivar performance in the environment with cold winters
(Borová hora Arboretum) or moderately dry summers (Dudince Spa Resort) revealed average growth rates for R. catawbiense 'Grandiflorum' and cv. 'Nova Zembla' and higher ones for $R$. catawbiense 'Album' in the first location but average values for both $R$. catawbiense genotypes and higher elongation growth for cv. 'Nova Zembla' in the latter one (LUKÁČIK et al., 2011), pointing on their cold and drought tolerance levels, respectively.

However, following the precipitation in the driest month and minimal temperature in the coldest month (normal 1960-1990) for areas of natural distribution of the studied botanical species (Table 3), we obtained completely different and sometimes also opposite results. Because of a relatively small variability in these climatic parameters among the species, we assume that it could be a result of genetic variability in the areas of natural distribution and horticultural selection process.

Table 3. Natural distribution of most frequent rhododendron species in the Mlyňany Arboretum IFE SAS (KRÜSSMANN, 1962) with local climate characteristics (sources: Global Biodiversity Information Facility (GBIF) - doi:10.15468 and CzEKALSKI (1998); WorldClim - Bioclim 6 and Bioclim 14). N - North, S - South, SW - South-West, Am - America, As - Asia, Eu Europe

\begin{tabular}{cccc}
\hline Species & Natural distribution & $\begin{array}{c}\text { Min temperature of the } \\
\text { coldest month }\left({ }^{\circ} \mathrm{C}\right)\end{array}$ & $\begin{array}{c}\text { Precipitation of the driest } \\
\text { month }(\mathrm{mm})\end{array}$ \\
\hline R. catawbiense & N Am - S Appalachian & $-4.9 \pm 1.5^{*}$ & $102 \pm 24$ \\
$R$. decorum & China - Yunnan, Sichuan & $-0.6 \pm 4.8$ & $10 \pm 4$ \\
R. fortunei & China - Chekiang $(1,000 \mathrm{~m})$ & $1.3 \pm 2.3$ & $35 \pm 11$ \\
$R$. macrophyllum & N Am - Pacific coast & $0.8 \pm 3.3$ & $10 \pm 10$ \\
R. ponticum & S Eu, SW As & $-3.9 \pm 5.9$ & $58 \pm 31$ \\
R. smirnowii & Caucasus $(1,500-2,500 \mathrm{~m})$ & $-6.6 \pm 1.4$ & $2 \pm 2$ \\
\hline
\end{tabular}

*average $\pm \mathrm{SD}$.

From our results we can conclude that most of rhododendron species and cultivars in the Mlyňany Arboretum IFE SAS collection were not or only slightly affected by drought. Strong or very strong water deficit was observed in almost $30 \%$ and $12 \%$ rhododendron species and cultivars, respectively. Shrub drought injury level was influenced only by the genotype. Among the most frequent rhododendron genotypes, the most drought-tolerant were $R$. catawbiense, $R$. ponticum, $R$. smirnowii and cvs. 'Boursault', 'Cunningham's White' and 'Purpureum Elegans'. As the least tolerant $R$. fortu$n e i$ and cv. 'Tamarindos' were indicated.

On the other hand, moderate injury dominated in the rhododendron frost damage test (more than 28 and $37 \%$ for species and cultivars, respectively). Strong and very strong frost injury were observed in 30\% species individuals and $15 \%$ cultivar individuals. Despite of no statistical difference between their reactions concerning all factors, we can order the most tolerant genotypes as follows: cv. 'Cunningham's White' $>R$. decorum $>$
$R$. fortunei and cv. 'Duke of York' $>R$. smirnowii $>$ cvs. 'Purpureum Elegans' and 'Tamarindos' $>$ R. macrophyllum and cv. 'Nova Zembla' $>R$. catawbiense $>$ $R$. ponticum. The least drought and frost tolerant genotypes should be replaced by new progressive cultivars.

\section{Acknowledgement}

This work was supported by the Scientific Grant Agency project of the Ministry of Education, Science, Research and Sport of the Slovak Republic, Vega 2/0183/14. We express special thanks to MSc. Michal Severa from the Silva Tarouca Research Institute for Landscape and Ornamental Gardening, Průhonice, Czech Republic for his help with the rhododendron species re-determination, to Dr. Ladislav Nad'o from the Institute of Forest Ecology SAS in Zvolen for statistical analysis performance and to the associate prof. Pavol Eliáš jun. from the Slovak Agricultural University in Nitra for technical support. 


\section{References}

Alkurdi, M.I.S., SupukA, J., 2016. Study of Mediterranean woody plants for hardiness in Central Europe conditions. Praha: Powerprint. 94 p.

AnisKo, T., Lindstrom, O.M., 1996. Seasonal changes in cold hardiness of Rhododendron L. 'Catawbiense Boursault'grown under continuous and periodic water stress. Journal of the American Society for Horticultural Science, 121 (2): 301-306.

Antonelli, A.L., Byther, R.S., Maleike, R.R, CollMAN, S.J., 2006. How to identify rhododendron and azalea problems. Extension bulletin (Washington State University. Cooperative Extension), 1229. Pullman, Wash.: Cooperative Extension, College of Agriculture \& Home Economics, Washington State University. 28 p.

Augé, R.M., Stodola, A.J.W., Moore, J.L., KlingeMan, W.E., Duan, X.G., 2003. Comparative dehydration tolerance of foliage of several ornamental crops. Scientia Horticulturae, 98: 511-516.

Cameron, R., Harrison-Murray, R., Fordham, M., Wilkinson, S., Davies, W., Atkinson, C., Else, M., 2008. Regulated irrigation of woody ornamentals to improve plant quality and precondition against drought stress. Annals of Applied Biology, 153: 49-61.

Caprar, M., Cantor, M., Sicora, C., 2011. Behavior of Rhododendron species to low and negative temperature in the Botanical Garden Jibou in 2002-2010. Bulletin of University of Agricultural Sciences and Veterinary Medicine Cluj - Napoca. Horticulture, 68 (1): 309-314.

CORDERO, R.A., NiLSEN, E.T., 2002. Effects of summer drought and winter freezing on stem hydraulic conductivity of Rhododendron species from contrasting climates. Tree Physiology, 22: 919-928.

Cox, P.A., 1985. The smaller rhododendrons. London: B.T. Batsford. $271 \mathrm{p}$.

CzeKalski, M., 1982. Injuries of rhododendrons in Poland caused by frost during winter 1978/1979. Roczniki Akademii Rolniczej w Poznaniu. Ogrodnictvo, no. 137: 3-14.

Czekalski, M., 1998. Rhododendrons in the former Soviet Union. Journal of American Rhododendron Society, 52: 2.

Ferus, P., HoŤKa, P., KonôPKová, J., PAstirčÁK, M., Majeská, M., Gubiš, J. 2016. Zdravotný stav zbierky rododendronov v Arboréte Mlyňany ÚEL SAV: Súčasnost' a vyhliadky do budúcnosti [Health state of rhododendron collection in the Mlyn̆any Arboretum IFE SAS: current state and future perspectives]. In BARTA, M., Ferus, P. (eds). Dendrologické dni v Arboréte Mlyn̆any SAV 2016. Dreviny v meniacom sa prostredí. Recenzovaný zbornik príspevkov z vedeckej konferencie. Vieska nad Žitavou, 5. októbra 2016. Mlyňany: Arborétum Mlyňany SAV, 2016, p. 76-81.
Pachauri, R.K., Meyer, L.A. (eds), 2015. Climate change 2014: synthesis report. Geneva: IPCC. 151 p.

Juhásová, G., Serbinová, K. 1997. Metódy hodnotenia zdravotného stavu drevín $\mathrm{v}$ mestskom prostredí [Methods for tree health state evaluation in urban environment]. In Pestovanie a ochrana rastlin $v$ mestskom prostredi, ošetrenie chránených a pamätných stromov. Zborník zo seminára. Nitra, 27. - 28. 5. 1997. Nitra : Ústav ekológie lesa SAV, p. $42-68$.

KE, S.S. 2007. Effect of soil drought stress on water use efficiency of Rhododendron fortunei leaves. Journal of Henan Normal University, 35 (2): 150-153.

KE, S.S., YANG, M.W., 2007a. Effect of water stress on photosynthetic physiological characteristics in leaves of Rhododendron fortunei and their response to light and temperature. Acta Horticulturae Sinica, 2007, 34 (4): 959-964.

KE, S.S., YANG, M.W. 2007b. Effect of water stress on antioxidant system and lipid peroxidation in leaves of Rhododendron fortunei. Acta Horticulturae Sinica, 34 (5): 1217-1222.

Kelly, J.D., 1994. Top causes of death in rhododendrons. Journal of American Rhododendron Society, 48 (2): [4 p.].

KRÜSSMANN, G., 1962. Handbuch der Laubgehölze. Band II. Berlin and Hamburg: Paul Parey. 608 p.

LARCHer, W., 2003. Physiological plant ecology. Berlin: Springer. 513 p.

Lim, C.C., Arora, R., Townsend, E.C. 1998. Comparing Gompertz and Richards functions to estimate freezing injury in Rhododendron using electrolyte leakage. Journal of American Society of Horticultural Science, 123 (2): 246-252.

LuKÁČIK, I., SARVAŠOvÁ, I., KRALIČKOvÁ, E., 2011. Vyhodnotenie vybraného sortimentu rodu Rhododendron v rozdielnych ekologických podmienkach [Selected assortment evaluation of genus Rhododendron in different ecological conditions]. In SALAŠ, P. (ed.). Rostliny v podmínkách měnícího se klimatu. Př́spěvky z konference ve dnech 20. - 21. 10. 2011 v Lednice. Úroda, vědecká př́loha časopisu. Praha: Profi Press, p. 350-358.

Melo, M., 2003. Climatic models and their utilization for assessment of climatic changes in Slovakia. $\mathrm{PhD}$ thesis. Bratislava: Geophysical Institute SAS. 155 p.

Nelson, S., 2000. Rhododendrons in the landscape. Portland: Timber Press. 215 p.

Neuner, G., Ambach, D., Aichler, K., 1999. Impact of snow cover on photoinhibition and winter desiccation in evergreen Rhododendron ferrugineum leaves during subalpine winter. Tree Physiology, 19: 725732.

Peng, Y., Reyes, J.L., Wei, H., Yang, Y., Karlson, D., Covarrubias, A.A., Krebs, S.L., Fessehaie, A., Arora, R., 2008. RcDhn5, a cold acclimation-re- 
sponsive dehydrin from Rhododendron catawbiense rescues enzyme activity from dehydration effects in vitro and enhances freezing tolerance in RcDhn5overexpressing Arabidopsis plants. Physiologia Plantarum, 134: 583-597.

ReILey, H.E., 2004. Success with rhododendrons and azaleas. Portland: Timber Press. 284 p.

Sharp, R.G., Else, M.A., Cameron, R.W., Davies, W.J., 2009. Water deficits promote flowering in via regulation of pre and post initiation development. Scientia Horticulturae, 120: 511-517.

SpanN, T.M., HeErema, R.J., 2010. A simple method for non-destructive estimation of total shoot leaf area in tree fruit crops. Scientia Horticulturae, 125 (3): 528-533.

Š́mbera, T., Šembera, I., Balajka, J., Hrabovská, J., Fekete, F., LAPIN, M., ŠŤAstnÝ, P., Tóth, T., 2015. Environmentálna štúdia územných dopadov klimatických zmien [Environmental study on climate change consequences in the land]. Nitra: Nitriansky samosprávny kraj. $138 \mathrm{p}$.

ŠIŠKA, B., ŠPÁNIK, F., REPA, Š., GÁLIK, M. 2005. Praktická biometeorológia [Practical biometeorology]. Nitra: Slovenská pol'nohospodárska univerzita. 144 p.

Wei, H., Dhanaraj, A.L., Arora, R., Rowland, L.J., Fu, Y., Sun, L., 2006. Identification of cold acclimation-responsive Rhododendron genes for lipid metabolism, membrane transport and lignin biosynthesis: importance of moderately abundant ESTs in genomic studies. Plant, Cell and Environment, 29: $558-570$.

Zhang, C.Q., Luo, J.F., Su, Y.F., 2002. The research of drought tolerance on 6 species of Rhododendron. Guangxi Zhiwu, 22 (2): 174-176.

Received October 17, 2017 Accepted December 4, 2017 